Marquette University

e-Publications@Marquette

College of Education Faculty Research and

Publications

Education, College of

$2-1-2000$

Clarifying the Effects of Parental Substance Abuse, Child Sexual Abuse, and Parental Caregiving on Adult Adjustment

Timothy Melchert

Marquette University, timothy.melchert@marquette.edu

Accepted version. Professional Psychology: Research and Practice, Vol. 31, No. 1 (February 2000):

54-69. DOI. (C) 2000 American Psychological Association. Used with permission.

This article may not exactly replicate the final version published in the APA journal. It is not the copy of record. 


\title{
Clarifying the Effects of Parental Substance Abuse, Child Sexual Abuse, and Parental Caregiving on Adult Adjustment
}

\author{
Timothy P. Melchert \\ Department of Counseling and Educational Psychology \\ Marquette University \\ Milwaukee, WI
}

\begin{abstract}
Parental alcoholism, childhood sexual abuse, and other forms of child maltreatment are generally viewed as contributing to adult adjustment problems. The long-term effects of these various factors, however, are actually not well understood. The present study found that the largest amount of variance in college students' psychological distress was explained by parental emotional abuse and neglect, with child sexual abuse, parental substance abuse, and other factors explaining additional but smaller amounts of variance in distress. This suggests that comprehensive conceptualizations of family influences on development will result in a more complete understanding of long-term adjustment outcomes than merely focusing on particular childhood risk factors.

Parental alcoholism and childhood sexual abuse (CSA) have received a tremendous amount of research, clinical, and policy attention in the past two decades, and there have been significant advances in knowledge regarding the effects of each of these factors (for reviews, see Briere, Berliner, Bulkley, Jenny, \& Reid, 1996; Brown \& Schmid, 1999). Large numbers of adult children of alcoholics


(ACOAs) and CSA survivors have also benefited from mental health services and support groups (for reviews, see Baer, Marlatt, \& McMahon, 1993; Wolfe, McMahon, \& Peters, 1997).

Despite these developments, there is still a great deal about the consequences of parental alcoholism, CSA, and other forms of child maltreatment that remains unclear. In particular, there are limited data to help explain why particular ACOAs and child abuse victims suffer from a variety of adjustment problems, whereas some others apparently do not. A better understanding of the diverse outcomes associated with these risk factors would be very helpful for informing clinical assessment, treatment planning, prevention efforts, and theory development.

Though Freud actually wrote little about the effects of different approaches to parenting (Symonds, 1949), a major legacy of the psychoanalytic approach (e.g., Horney, 1933; Levy, 1931) has been a focus on the effects of parental acceptance (and its obverse, rejection or emotional abuse) and parental responsiveness (and its obverse, emotional neglect). Parental approaches to behavioral control also figured prominently in several early models of child socialization (e.g., Baldwin, 1949). Since that time, other aspects of parenting have also received extensive examination. Kempe, Silverman, Steele, Droegemueller, and Silver (1962) were the first researchers to bring widespread professional attention to the problem of child physical abuse. CSA and parental alcoholism also began receiving widespread attention somewhat later (cf. Armstrong, 1978; Black, 1981).

The long-term consequences of each of these factors are not yet well understood, however, despite significant empirical investigation. In particular, the effects of the more recently investigated variables (physical and sexual abuse and parental alcoholism) relative to other aspects of parental caregiving are not clear. For example, many studies have found that parental alcoholism is correlated with a variety of psychological symptoms in ACOAs, including depression, anxiety, substance abuse, relationship problems, and antisocial behavior (Sher, 1997; Steinhausen, 1995). It is also clear, however, that many ACOAs function well and do not show signs of serious maladjustment.

Professional Psychology: Research and Practice, Vol. 31, No. 1 (February 2000): pg. 64-69. DOI. This article is (C American Psychological Association and permission has been granted for this version to appear in e-Publications@Marquette. American Psychological Association does not grant permission for this article to be further copied/distributed or hosted elsewhere without the express permission from American Psychological Association. 
A variety of theories have been proposed to explain these findings (e.g., Collins, Leonard, \& Searles, 1990), but the specific effects of parental substance abuse on children's development, independent of other aspects of family functioning, have received relatively little empirical attention. Most of the studies that have examined this question have found that parental alcoholism does not explain additional variance in maladjustment after the effects of general family dysfunction are partialled out (e.g., Harrington \& Metzler, 1997; Werner \& Broida, 1991). Other studies, however, have found the opposite result (e.g., Buelow, 1995; Rubio-Stipec, Bird, Canino, Bravo, \& Alegria, 1991).

Researchers have found that a history of CSA is also associated with a variety of negative psychosocial consequences (Kendall-Tackett, Williams, \& Finkelhor, 1993). Posttraumatic stress disorder and low self-esteem are relatively common outcomes associated with this form of abuse, though a wide range of symptomatic and pathological behavior has been associated with CSA. Studies have also found, however, that up to $40 \%$ of sexually abused children are seemingly not symptomatic at all (Berliner \& Elliott, 1996). As with parental substance abuse, other aspects of family dysfunction may account for the adverse outcomes associated with CSA. The research on these questions also provides inconsistent findings. For example, Nash, Hulsey, Sexton, Harralson, and Lambert (1993) found that no additional variance in level of adjustment was explained by a history of CSA after the effects of general family dysfunction had been partialled out, whereas the findings of Harter, Alexander, and Neimeyer (1988) supported the opposite conclusion.

The inconsistent research findings regarding the previously mentioned questions present a significant difficulty for practitioners because of the high prevalence of childhood risk factors such as CSA, parental alcoholism, and other types of family dysfunction in the clinical population. Explanations for adult maladjustment and treatment planning in these cases often must rely on clinical experience and theoretical approaches to psychotherapy without the clear support of empirical evidence. Theory and clinical experience obviously are valuable tools for mental health practice, but empirical support for our assessments and treatments is also steadily increasing

Professional Psychology: Research and Practice, Vol. 31, No. 1 (February 2000): pg. 64-69. DOI. This article is (C) American Psychological Association and permission has been granted for this version to appear in e-Publications@Marquette. American Psychological Association does not grant permission for this article to be further copied/distributed or hosted elsewhere without the express permission from American Psychological Association. 
in importance. Therefore, finding answers to these questions is a matter of some import.

Some of the inconsistent findings in this research are likely to have resulted from the manner in which the risk factors were defined. With regard to the consequences of CSA, for example, most studies have combined intrafamilial and extrafamilial abuse when participants were divided into treatment and control groups. It appears, however, that intrafamilial sexual abuse has greater negative effects than extrafamilial abuse (Briere \& Elliott, 1993; Finkelhor \& Baron, 1986). Much of the research has also combined unwanted sexual contact with willing sexual contact as well as unwanted and willing noncontact sexual experiences (e.g., exhibitionism). Definitions of CSA are unclear and controversial, but certainly unwanted and forced sexual contact are abusive. There is less agreement regarding the abusiveness of some willing noncontact sexual experiences, particularly with nonrelatives. No clear boundaries between these categories of sexual experience may exist, but there are important distinctions between them nonetheless. Much of the research regarding the consequences of CSA has lumped together diverse categories of sexual experience, and the associations found between CSA and adjustment outcomes have been weakened as a result (see Rind, Tromovitch, \& Bauserman, 1998).

Most of the studies that have examined the independent effects of CSA and parental substance abuse beyond the effects of general family dysfunction have also used global measures of family functioning such as the Family Adaptability and Cohesion Evaluation Scale (Olson, Russell, \& Sprenkle, 1983; see Harter et al., 1988) or the average score from the Family Environment Scale (Moos \& Moos, 1986; see Briere \& Elliott, 1993). Global measures of family functioning are obviously useful for some purposes, but it can be difficult to infer what specific aspects of parental caregiving and family functioning are assessed by these measures. For example, parental substance abuse and CSA are presumably dysfunctional for families, and it is unclear which aspects of this dysfunction may be partialled out by global measures of family functioning before the independent effects of CSA or parental substance abuse are then examined. Emotional abuse isalso commonly present in cases of sexual and physical abuse (Kolko, 1996), and there is a tendency for parental 
substance abuse and CSA to occur together (Faust, Runyon, \& Kenny, 1995). Therefore, examining the effects of any one of these variables, while controlling for the effects of all other family processes in a global manner, will result in highly generalized findings that have limited usefulness for identifying the major risk and protective factors regarding long-term psychological maladjustment. Clinical assessment and treatment planning in cases that include these factors would also be clearer and potentially more useful if the relationships between these factors and adult adjustment outcomes were clarified.

\section{An Exploratory Family History Study}

Participants were recruited from a psychology department subject pool at a large research university in the southwestern United States. The sample (which has not been used in any other study) included 255 college students, $49 \%$ of whom were female. The average age of the sample was young $(M=20.41$ years, $S D=4.40$, range $=18-49)$, and $79 \%$ identified their ethnicity as European American, 12\% indicated Latin American, 4\% indicated African American, 3\% indicated Asian American, and 2\% identified other ethnic backgrounds.

With regard to parental substance abuse, $5 \%$ of the women and $6 \%$ of the men indicated that their fathers were "alcoholic or addicted to drugs," whereas $7 \%$ of the women and $5 \%$ of the men indicated that their mothers were substance dependent (SD). Overall, $10 \%$ of the sample indicated that their mothers or fathers were SD.

With regard to CSA, intrafamilial sexual abuse was defined as "any form of sexual contact" before age 18 with one's mother, father, or "any other relatives who were older than you (for example, brothers, sisters, grandparents, cousins, uncles)." Extrafamilial sexual abuse was defined as unwanted or physically forced sexual contact with individuals other than relatives before the age of 18 . Fifteen percent of the women reported experiencing incest, and $15 \%$ reported extrafamilial CSA, with $25 \%$ of the present sample reporting experiencing one or both of these types of sexual abuse. For the men, $18 \%$ reported experiencing incest, and $13 \%$ reported extrafamilial CSA, with $27 \%$ of the present sample reporting experiencing one or both of these types of abuse.

Professional Psychology: Research and Practice, Vol. 31, No. 1 (February 2000): pg. 64-69. DOI. This article is (C) American Psychological Association and permission has been granted for this version to appear in e-Publications@Marquette. American Psychological Association does not grant permission for this article to be further copied/distributed or hosted elsewhere without the express permission from American Psychological Association. 
There also was a significant amount of overlap between those who reported a history of incest and parental SD: $21 \%$ of those who reported a history of incest also reported that their parents were SD (compared with $5 \%$ of those who reported no history of incest), and $47 \%$ of those who reported parental SD also reported a history of incest (compared with $14 \%$ who reported no parental SD), $\mathrm{X}^{2}(1, N=$ $255)=12.38, p<.001$.

The Beck Depression Inventory (BDI; Beck, Steer, Epstein, \& Brown, 1993) and the Global Severity Index of the Brief Symptom Inventory (BSI; Derogatis, 1992) were used to measure general psychological distress. The BDI and BSI Global Severity Index scores were highly correlated $(r=.76)$, so a single standardized measure of psychological distress was computed for each individual. Women obtained significantly higher distress scores than men on this measure (female $M=.16, S D=1.09$; male $M=-.16, S D=.73), F(1,253)=$ $7.38, p=.007$.

The Family Background Questionnaire (FBQ; Melchert \& Sayger, 1998 ) is a 179-item instrument designed to assess a variety of familyof-origin characteristics. The FBQ subscales that were used in the present study included Mother and Father Acceptance (a continuum of respectful approval and acceptance to rejection and emotional abuse), Mother and Father Responsiveness (a continuum of supportive responsiveness to emotional neglect), Mother and Father Physical Abuse (the use of physical discipline and violence), Control (a behavioral restrictiveness continuum ranging from autocratic to permissive), and Mother and Father Decision Making Style (a continuum with clear, reasonable, and flexible decision making at one end and its opposite at the other end). Cronbach's alpha internal consistency coefficients for these subscales ranged from .82 to .96 (2week test-retest coefficients ranged from .73 to .93), and substantial evidence has been found regarding their validity (Melchert, 1998; Melchert \& Sayger, 1998).

Given the different levels of psychological distress reported by the men and women, correlations between each of the study variables were computed separately for each gender (see Table 1). These analyses found that parental Acceptance, Responsiveness, and Decision Making Style were at least moderately correlated with each

Professional Psychology: Research and Practice, Vol. 31, No. 1 (February 2000): pg. 64-69. DOI. This article is (C) American Psychological Association and permission has been granted for this version to appear in e-Publications@Marquette. American Psychological Association does not grant permission for this article to be further copied/distributed or hosted elsewhere without the express permission from American Psychological Association. 
other. A reported history of parental SD and incest were more weakly associated with the other aspects of family functioning, though both tended to have stronger correlations for the men than for the women. The correlations between the psychological distress scores and the family-of-origin variables were in each case stronger for the women than the men, except for Mother and Father Physical Abuse. With the exception of Mother Responsiveness for the males, the strongest correlations for both the women and men were for Mother and Father Acceptance and Mother and Father Responsiveness (emotional abuse and neglect, respectively, at the dysfunctional ends of the scales).

Although Mother and Father Decision Making scores were substantially correlated with distress, the level of behavioral restrictiveness as represented by the Control scores was not. Post hoc analyses, however, found that Control scores had a significant curvilinear relationship with distress scores. For the women, $16 \%$ of the variance in distress scores was explained by a quadratic regression analysis, with moderate levels of control being associated with lower distress, whereas both low and high control were associated with higher distress $(R=.40), F(2,121)=11.68, p<.0001$. The quadratic regression analysis between control and distress was nonsignificant for the men, however.

These correlational results suggest that the participants', and especially the female participants', current levels of distress were affected more by their perceptions of the emotional qualities of their childhood relationships with their parents than by specific reports of parental SD or CSA. To assess whether this pattern also held within the ACOA and incest survivor groups, correlations were computed between the distress scores and the family-of-origin variables for each of these two risk groups. The pattern of correlations within these groups was quite similar to the pattern found for the study sample as a whole.

Hierarchical multiple regression analyses were computed to clarify the unique effects of the various family-of-origin variables on adult psychological distress. Given the different patterns of correlations for the women and men, the analyses were conducted separately by gender. The order of entry for the predictor variables was determined by the strength of their association with current

Professional Psychology: Research and Practice, Vol. 31, No. 1 (February 2000): pg. 64-69. DOI. This article is (C) American Psychological Association and permission has been granted for this version to appear in e-Publications@Marquette. American Psychological Association does not grant permission for this article to be further copied/distributed or hosted elsewhere without the express permission from American Psychological Association. 
distress and the need to establish whether parental SD and incest explained any additional variance in distress after the effects of the other variables had been partialled out. The Mother and Father Acceptance and Responsiveness variables were entered first because they generally had the strongest correlations with distress scores. The Control and Decision Making variables were entered next, which were followed by Physical Abuse. Parental SD and CSA were entered last, and extrafamilial and intrafamilial CSA were entered separately to determine whether incest had additional effects on distress beyond the effects of extrafamilial sexual abuse.

The multiple regression analyses found that quite substantial amounts of variance in participants' current distress was explained by the family-of-origin variables. More than one half of the variance in women's distress and more than one quarter of the variance in men's distress was accounted for by these variables (see Table 2). In both cases, Mother and Father Acceptance explained substantial amounts of variance in distress, and the behavioral control variables explained no additional variance after the effects of parental Acceptance and Responsiveness had been partialled out. Mother Physical Abuse scores did explain a significant amount of additional variance for the men but not the women, whereas parental SD explained significant amounts of additional variance for both genders. Extrafamilial CSA did not explain any additional variance in distress, but for both genders intrafamilial incest explained a significant amount of additional distress score variance. (When parental SD, extrafamilial CSA, and incest are entered into the analysis first before the other independent variables, the results are similar. For the sample as a whole, parental SD was significant and accounted for $3 \%$ of the variance, extrafamilial CSA was not significant, incest was significant and accounted for $9 \%$ of the variance, Mother Acceptance was significant and accounted for $16 \%$ of the variance, and Father Acceptance was significant and accounted for $4 \%$ of the variance. After these variables entered the equation, the rest of the independent variables were nonsignificant in predicting distress score variance.)

Our findings suggest that childhood history may have a substantial influence on adult psychological adjustment. Several questions need thorough investigation, however, before this conclusion is firmly supported. In addition to the possibility of third variables

Professional Psychology: Research and Practice, Vol. 31, No. 1 (February 2000): pg. 64-69. DOI. This article is (C) American Psychological Association and permission has been granted for this version to appear in e-Publications@Marquette. American Psychological Association does not grant permission for this article to be further copied/distributed or hosted elsewhere without the express permission from American Psychological Association. 
(e.g., genetic inheritance) accounting for the childhood history-adult distress relationship, the retrospective assessment of childhood history in this study is dependent on the reliability of participants' childhood memories. Readers should keep in mind that, although many childhood memories clearly are not accurate (Schacter, 1995), research has also failed to find evidence that individuals tend to exaggerate childhood adversity that they may have experienced (Maughan \& Rutter, 1997). The results based on the college student sample used here also cannot be generalized to clinical populations nor to the population in general. This study also used somewhat broad self-definitions of sexual abuse, which could have weakened the correlations that might have been found by differentiating between childhood versus adolescent abuse or by examining particular types of CSA such as those involving physical force or intercourse.

\section{Implications and Applications}

Practitioners should consider the potentially strong effects of parental acceptance and responsiveness when working with ACOAs and CSA survivors. It appears that emotional aspects of parent-child relationships can have a stronger association with later psychological distress than either parental SD or CSA, particularly for women. This also helps explain why some ACOAs and CSA survivors show few or no signs of psychological maladjustment, because the relatively strong effects of parental acceptance and responsiveness may have protected them from the adverse but weaker effects associated with parental SD and sexual abuse. A consideration of level of parental responsiveness and acceptance is also important for explaining distress in individuals who report none of the risk factors of parental SD or physical or sexual abuse. This does not suggest that parental SD and incest are unimportant, because both appear to have unique adverse consequences beyond the effects of other important aspects of maladaptive parental caregiving. The specific events involved, the experience of those events, as well as the effects of the events must be addressed clinically. However, parental SD and incest also occur within a broader context of parental caregiving, which must be explored and understood because a substantially more complete explanation of adult distress results from considering the emotional

Professional Psychology: Research and Practice, Vol. 31, No. 1 (February 2000): pg. 64-69. DOI. This article is (C) American Psychological Association and permission has been granted for this version to appear in e-Publications@Marquette. American Psychological Association does not grant permission for this article to be further copied/distributed or hosted elsewhere without the express permission from American Psychological Association. 
qualities of parent-child relationships in addition to particular risk factors.

Several writers have expressed concern that there has been a tendency for the general public to stereotype and pathologize ACOAs and CSA survivors as a result of the large amount of attention that parental alcoholism and CSA have received in recent years.

Practitioners may also do the same. For example, Burk and Sher (1988) and Lindsay and Read (1994) warned that some psychotherapists appear to apply confirmatory biases where common physical and psychological experiences are interpreted as symptomatic of being "codependent" or having a sexual abuse history while alternative explanations are discounted. Attributing adult outcomes to factors such as these without also considering other explanations for the outcomes clearly will result in a limited understanding of individuals' development. Taking a more comprehensive and empirically supported approach to assessing the influence of family-oforigin experiences on development will help both practitioners and their clients to avoid such biases.

There has also been a persistent controversy regarding the importance of behavioral restrictiveness on children's development (see Rothbaum \& Weisz, 1994). It appears, however, that differentiating between the decision-making style that parents use around issues of control and discipline and the level of behavioral restrictiveness that they exercise may provide a resolution to this question. For example, parental decision making style was moderately correlated with adult distress in the present study, whereas level of parental restrictiveness had only a weak relationship with distress for the women (and this may be only the first study to find a curvilinear relationship between restrictiveness and later distress, though no such relationship was detected for the men). This question needs further exploration, both in the clinical context and through systematic empirical work.

Many prevention and early intervention programs for children focus on physical and sexual abuse rather than emotional abuse and neglect (often called "psychological maltreatment"). For example, the large majority of child protective service investigations involve physical and sexual abuse because they are much easier to identify than

Professional Psychology: Research and Practice, Vol. 31, No. 1 (February 2000): pg. 64-69. DOI. This article is (C) American Psychological Association and permission has been granted for this version to appear in e-Publications@Marquette. American Psychological Association does not grant permission for this article to be further copied/distributed or hosted elsewhere without the express permission from American Psychological Association. 
emotional abuse (Hart, Brassard, \& Karlson, 1996). Perhaps more attention should also be given to emotional aspects of parental caregiving, however, because of the importance of their relationship to later adjustment.

\section{Footnotes}

${ }^{1}$ This measure was computed by first converting scores on the BDI and the BSI Global Severity Index to $z$ scores (because the two instruments used a different metric). The mean of these two $z$ scores was then computed for each individual, creating a single composite measure of distress.

2 There were significant gender differences $(p<.01)$ in scores on the BDI (female $M=9.01, S D=7.92$; male $M=6.02, S D=5.52$ ), on the FBQ Control subscale (female $M=2.40, S D=.59$; male $M=2.13, S D$ $=.67$; women reported a higher level of behavioral restrictiveness), and the FBQ Father Physical Abuse subscale (female $M=3.92, S D=$ 1.00 ; male $M=3.50, S D=1.10$; men reported more paternal physical abuse). No other significant gender differences were found.

${ }^{3}$ The correlation matrices for the two risk groups are available from Timothy P. Melchert.

\section{References}

Armstrong, L. (1978). Kiss daddy goodnight: A speak-out on incest. New York: Pocket Books.

Baer, J. S., Marlatt, G. A., \& McMahon, R. J. (1993). Addictive behaviors across the life span: Prevention, treatment, and policy issues. Newbury Park, CA: Sage.

Baldwin, A. L. (1949). The effect of home environment on nursery school behavior. Child Development, 29, 49-62.

Beck, A. T., Steer, R. A., Epstein, N., \& Brown, G. (1993). Beck Depression Inventory manual. San Antonio, TX: Psychological Corporation.

Berliner, L., \& Elliott, D. M. (1996). Sexual abuse of children. In J.Briere, L.Berliner, J. A.Bulkley, C.Jenny, \& T.Reid (Eds.), The APSAC handbook on child maltreatment (pp. 51-71). Thousand Oaks, CA: Sage.

Professional Psychology: Research and Practice, Vol. 31, No. 1 (February 2000): pg. 64-69. DOI. This article is (C) American Psychological Association and permission has been granted for this version to appear in e-Publications@Marquette. American Psychological Association does not grant permission for this article to be further copied/distributed or hosted elsewhere without the express permission from American Psychological Association. 
NOT THE PUBLISHED VERSION; this is the author's final, peer-reviewed manuscript. The published version may be accessed by following the link in the citation at the bottom of the page.

Black, C. (1981). It will never happen to me. Denver, CO: ACT Publishers.

Briere, J., Berliner, L., Bulkley, J. A., Jenny, C., \& Reid, T. (1996). The APSAC handbook on child maltreatment. Thousand Oaks, CA: Sage.

Briere, J., \& Elliott, D. M. (1993). Sexual abuse, family environment, and psychological symptoms: On the validity of statistical control. Journal of Consulting and Clinical Psychology, 61, 284-288.

Brown, S., \& Schmid, J. (1999). Adult children of alcoholics. In P. J.Ott \& R. E.Tarter (Eds.), Sourcebook on substance abuse: Etiology, epidemiology, assessment, and treatment (pp. 416-429). Boston, MA: Allyn \& Bacon.

Buelow, G. (1995). Comparing students from substance abusing and dysfunctional families: Implications for counseling. Journal of Counseling \& Development, 73, 327-330.

Burk, J. P., \& Sher, K. J. (1988). The "forgotten children" revisited: Neglected areas of COA research. Clinical Psychology Review, 8, 285-302.

Collins, R. L., Leonard, K. E., \& Searles, J. S. (Eds.). (1990). Alcohol and the family: Research and clinical perspectives. New York: Guilford Press.

Derogatis, L. R. (1992). The Brief Symptom Inventory (BSI): Administration, scoring and procedures manual-II. Baltimore: Johns Hopkins University School of Medicine, Clinical Psychometrics Research Unit.

Faust, J., Runyon, M. K., \& Kenny, M. C. (1995). Family variables associated with the onset and impact of intrafamilial childhood sexual abuse. Clinical Psychology Review, 15, 443-456.

Finkelhor, D., \& Baron, L. (1986). High-risk children. In D.Finkelhor (Ed.), A sourcebook on child sexual abuse (pp. 60-88). Newbury Park, CA: Sage.

Harrington, C. M., \& Metzler, A. E. (1997). Are adult children of dysfunctional families with alcoholism different from adult children of dysfunctional families without alcoholism? A look at committed, intimate relationships. Journal of Counseling Psychology, 44, 102-107.

Hart, S. N., Brassard, M. R., \& Karlson, H. C. (1996). Psychological maltreatment. In J.Briere, L.Berliner, J. A.Bulkley, C.Jenny, \& T.Reid

Professional Psychology: Research and Practice, Vol. 31, No. 1 (February 2000): pg. 64-69. DOI. This article is (C) American Psychological Association and permission has been granted for this version to appear in e-Publications@Marquette. American Psychological Association does not grant permission for this article to be further copied/distributed or hosted elsewhere without the express permission from American Psychological Association. 
NOT THE PUBLISHED VERSION; this is the author's final, peer-reviewed manuscript. The published version may be accessed by following the link in the citation at the bottom of the page.

(Eds.), The APSAC handbook on child maltreatment (pp. 79-89). Thousand Oaks, CA: Sage.

Harter, S., Alexander, P. C., \& Neimeyer, R. A. (1988). Long-term effects of incestuous child abuse in college women: Social adjustment, social cognition, and family characteristics. Journal of Consulting and Clinical Psychology, 56, 5-8.

Horney, K. (1933). Maternal conflicts. American Journal of Orthopsychiatry, 3, 355-363.

Kempe, C. H., Silverman, F. M., Steele, B. F., Droegemueller, W., \& Silver, H. K. (1962). The battered-child syndrome. JAMA: Journal of the American Medical Association, 181, 145-155.

Kendall-Tackett, K. A., Williams, L. M., \& Finkelhor, D. (1993). Impact of sexual abuse on children: A review and synthesis of recent empirical studies. Psychological Bulletin, 113, 164-180.

Kolko, D. J. (1996). Child physical abuse. In J.Briere, L.Berliner, J. A.Bulkley, C.Jenny, \& T.Reid (Eds.), The APSAC handbook on child maltreatment (pp. 21-50). Thousand Oaks, CA: Sage.

Levy, D. M. (1931). Maternal over-protection and rejection. Journal of Nervous and Mental Diseases, 73, 65-77.

Lindsay, D. S., \& Read, J. D. (1994). Psychotherapy and memories of childhood sexual abuse: A cognitive perspective. Applied Cognitive Psychology, 8, 281-338.

Maughan, B., \& Rutter, M. (1997). Retrospective reporting of childhood adversity: Issues in assessing long-term recall. Journal of Personality Disorders, 11, 19-33.

Melchert, T. P. (1998). Testing the validity of an instrument for assessing family of origin history. Journal of Clinical Psychology, 54, 863-875.

Melchert, T. P., \& Sayger, T. V. (1998). The development of an instrument for assessing family of origin characteristics. Educational and Psychological Measurement, 58, 99-118.

Moos, R., \& Moos, B. (1986). Family Environment Scale manual (2nd ed.). Palo Alto, CA: Consulting Psychologists Press.

Professional Psychology: Research and Practice, Vol. 31, No. 1 (February 2000): pg. 64-69. DOI. This article is (C) American Psychological Association and permission has been granted for this version to appear in e-Publications@Marquette. American Psychological Association does not grant permission for this article to be further copied/distributed or hosted elsewhere without the express permission from American Psychological Association. 
NOT THE PUBLISHED VERSION; this is the author's final, peer-reviewed manuscript. The published version may be accessed by following the link in the citation at the bottom of the page.

Nash, M. R., Hulsey, T. L., Sexton, M. C., Harralson, T. L., \& Lambert, W. (1993). Long-term sequelae of childhood sexual abuse: Perceived family environment, psychopathology, and dissociation. Journal of Consulting and Clinical Psychology, 61, 276-283.

Olson, D. H., Russell, C. S., \& Sprenkle, D. H. (1983). Circumplex model of marital and family systems: VI. Theoretical update. Family Process, $22,69-83$.

Rind, B., Tromovitch, P., \& Bauserman, R. (1998). A meta-analytic examination of assumed properties of child sexual abuse using college samples. Psychological Bulletin, 124, 22-53.

Rothbaum, F., \& Weisz, J. R. (1994). Parental caregiving and child externalizing behavior in nonclinical samples: A meta-analysis. Psychological Bulletin, 116, 55-74.

Rubio-Stipec, M., Bird, H., Canino, G., Bravo, M., \& Alegria, M. (1991). Children of alcoholic parents in the community. Journal of Studies on Alcohol, 52, 78-88.

Schacter, D. L. (1995). Memory distortion: History and current status. In D. L.Schacter (Ed.), Memory distortion (pp. 1-46). Cambridge, MA: Harvard University Press.

Sher, K. J. (1997). Psychological characteristics of children of alcoholics. Alcohol Health and Research World, 21, 247-254.

Steinhausen, H.-C. (1995). Children of alcoholic parents: A review. European Child and Adolescent Psychiatry, 4, 143-152.

Symonds, P. M. (1949). The dynamics of parent-child relationships. New York: Columbia University.

Werner, L. J., \& Broida, J. P. (1991). Adult self-esteem and locus of control as a function of familial alcoholism and dysfunction. Journal of Studies on Alcohol, 52, 249-252.

Wolfe, D. A., McMahon, R. J., \& Peters, R. D. (1997). Child Abuse: New directions in prevention and treatment across the lifespan. Thousand Oaks, CA: Sage.

Professional Psychology: Research and Practice, Vol. 31, No. 1 (February 2000): pg. 64-69. DOI. This article is (C) American Psychological Association and permission has been granted for this version to appear in e-Publications@Marquette. American Psychological Association does not grant permission for this article to be further copied/distributed or hosted elsewhere without the express permission from American Psychological Association. 
NOT THE PUBLISHED VERSION; this is the author's final, peer-reviewed manuscript. The published version may be accessed by following the link in the citation at the bottom of the page.

\section{Appendix}

Table I

Correlations Between the Study Variables

\begin{tabular}{|c|c|c|c|c|c|c|c|c|c|c|c|c|c|}
\hline Variable & 1 & 2 & 3 & 4 & 5 & 6 & 7 & 8 & 9 & 10 & 11 & 12 & 13 \\
\hline \multicolumn{14}{|c|}{ Women } \\
\hline 1. Distress & - & -.58 & -.64 & -.52 & -.54 & -.13 & -.44 & -.50 & -.24 & -.20 & -.23 & -.19 & -.40 \\
\hline 2. Mo acceptance & & - & .57 & .79 & .42 & .21 & .69 & .39 & .34 & .11 & .15 & .30 & .31 \\
\hline 3. Fa acceptance & & & - & .44 & .75 & -.02 & .44 & .74 & .12 & .18 & .08 & .19 & .12 \\
\hline 4. Mo responsiveness & & & & - & .53 & .05 & .74 & 45 & .22 & 01 & .18 & 31 & .24 \\
\hline 5. Fa responsiveness & & & & & - & -.09 & .48 & .77 & .06 & .03 & .06 & .18 & .14 \\
\hline 6. Control & & & & & & - & -.04 & -.13 & .21 & .19 & -.12 & .01 & -.04 \\
\hline 7. Mo decision making & & & & & & & - & .66 & .25 & .01 & .14 & .32 & .25 \\
\hline 8. Fa decision making & & & & & & & & - & .05 & .05 & .03 & .22 & .11 \\
\hline 9. Mo physical abuse & & & & & & & & & - & .73 & .09 & .18 & .13 \\
\hline 10. Fa physical abuse & & & & & & & & & & - & .01 & -.03 & .01 \\
\hline 11. Parental SD & & & & & & & & & & & - & .12 & .15 \\
\hline 12. Extrafamilial CSA & & & & & & & & & & & & - & .16 \\
\hline 13. Incest & & & & & & & & & & & & & - \\
\hline \multicolumn{14}{|c|}{ Men } \\
\hline 1. Distress & 一 & -.39 & -.42 & -.24 & -.40 & -.05 & -.28 & -.29 & -.36 & -.32 & -.07 & -.07 & -.36 \\
\hline 2. Mo acceptance & & - & .78 & 69 & .60 & .12 & .67 & 54 & .34 & 36 & .18 & .12 & 37 \\
\hline 3. Fa acceptance & & & - & .56 & .82 & .08 & .55 & .74 & .29 & .46 & .37 & .20 & 36 \\
\hline 4. Mo responsiveness & & & & - & .68 & .04 & .63 & .51 & .06 & .15 & .09 & .15 & .15 \\
\hline 5. Fa responsiveness & & & & & - & -.02 & .59 & .76 & .21 & .35 & .30 & .21 & .36 \\
\hline 6. Control & & & & & & - & .16 & .05 & .07 & .00 & -.05 & .01 & .07 \\
\hline 7. Mo decision making & & & & & & & - & .75 & .29 & .22 & .04 & .11 & 33 \\
\hline 8. Fa decision making & & & & & & & & - & .23 & .28 & .20 & .19 & 37 \\
\hline 9. Mo physical abuse & & & & & & & & & - & .78 & .31 & .02 & .26 \\
\hline 10. Fa physical abuse & & & & & & & & & & - & 42 & 03 & 21 \\
\hline II. Parental SD & & & & & & & & & & & - & .25 & .26 \\
\hline 12. Extrafamilial CSA & & & & & & & & & & & & - & .03 \\
\hline 13. Incest & & & & & & & & & & & & & - \\
\hline
\end{tabular}

Note. All of the family history variables are scored so that high scores indicate higher levels of family functioning. Correlations $>.23, p<.01 ;$ correlations $>.29, p<.001 . \mathrm{Mo}=$ mother; $\mathrm{Fa}=$ father; $\mathrm{SD}=$ substance dependent; $\mathrm{CSA}=$ childhood sexual abuse.

Professional Psychology: Research and Practice, Vol. 31, No. 1 (February 2000): pg. 64-69. DOI. This article is (C) American Psychological Association and permission has been granted for this version to appear in e-Publications@Marquette. American Psychological Association does not grant permission for this article to be further copied/distributed or hosted elsewhere without the express permission from American Psychological Association. 
NOT THE PUBLISHED VERSION; this is the author's final, peer-reviewed manuscript. The published version may be accessed by following the link in the citation at the bottom of the page.

Table 2

Hierarchical Multiple Regression Results for the Distress Scores

\begin{tabular}{|c|c|c|c|c|}
\hline Independent variable & $R$ & Adjusted $R^{2}$ & $F$ for increase in $R^{2}$ & $s r^{2}$ \\
\hline \multicolumn{5}{|c|}{ Women } \\
\hline Mo acceptance & .58 & .33 & $56.37^{* *}$ & .33 \\
\hline Fa acceptance & .68 & .46 & $27.79 * *$ & .13 \\
\hline Mo responsiveness & .69 & .47 & 2.99 & .01 \\
\hline Fa responsiveness & .69 & .46 & 0.55 & .00 \\
\hline Control $^{*}$ & .70 & .47 & 2.02 & .01 \\
\hline Mo decision making style & .70 & .46 & 0.01 & .00 \\
\hline Fa decision making style & .70 & .46 & 0.05 & .00 \\
\hline Mo physical abuse & .71 & .46 & 1.72 & .01 \\
\hline Fa physical abuse & .71 & .46 & 0.18 & .00 \\
\hline Parental SD & .72 & .48 & $4.51^{*}$ & .02 \\
\hline Extrafamilial CSA & .72 & .47 & 0.29 &, 00 \\
\hline Incest & .77 & .54 & $16.60^{* *}$ & .07 \\
\hline \multicolumn{5}{|c|}{ Men } \\
\hline Mo acceptance & .39 & .15 & $19.78^{* * *}$ & .15 \\
\hline $\mathrm{Fa}$ acceptance & .43 & .17 & $4.83^{*}$ & .04 \\
\hline Mo responsiveness & .44 & .17 & 0.24 & .00 \\
\hline Fa responsiveness & .47 & .19 & $3.95^{\circ}$ & .03 \\
\hline Control $^{2}$ & .47 & .18 & 0.07 & .00 \\
\hline Mo decision making style & .47 & .18 & 0.08 & .01 \\
\hline Fa decision making style & .48 & .18 & 0.94 & .01 \\
\hline Mo physical abuse & .52 & .21 & $5.47^{*}$ & .04 \\
\hline Fa Physical abuse & .52 & .21 & 0.49 & .00 \\
\hline Parental SD & .54 & .23 & $3.72^{*}$ & .03 \\
\hline Extrafamilial CSA & .56 & .24 & 2.93 & .02 \\
\hline Incest & .59 & .27 & $4.64 *$ & .03 \\
\hline
\end{tabular}

a The addition of the quadratic term for control resulted in a nonsignificant effect. As a result, it was excluded from the analysis because of the additional degree of freedom otherwise required. Mo $=$ mother; Fa $=$ father: $\mathrm{SD}=$ substance dependence: $\mathrm{CSA}=$ childhood sexual abuse.

$* p<.05 .{ }^{* *} p<.001$.

Professional Psychology: Research and Practice, Vol. 31, No. 1 (February 2000): pg. 64-69. DOI. This article is (C) American Psychological Association and permission has been granted for this version to appear in e-Publications@Marquette. American Psychological Association does not grant permission for this article to be further copied/distributed or hosted elsewhere without the express permission from American Psychological Association. 